\title{
DNA barcoding of rumen flukes (Paramphistomidae) from bovines in Germany and Austria
}

\author{
Sandra Wiedermann ${ }^{1} \cdot$ Josef Harl ${ }^{2} \cdot$ Hans-Peter Fuehrer $^{1} \cdot$ Sandra Mayr $^{3} \cdot$ Juliane Schmid $^{3} \cdot$ Barbara Hinney $^{1}\left({ }^{(0)}\right.$. \\ Steffen Rehbein ${ }^{3}$
}

Received: 13 August 2021 / Accepted: 7 October 2021 / Published online: 18 October 2021

(c) The Author(s) 2021

\begin{abstract}
Rumen flukes have received growing veterinary attention in western and central Europe during the past two decades because of an increase in prevalence of infection in cattle and sheep, including cases of severe clinical disease. Historically, rumen fluke infections in Europe were assumed to be caused mainly by Paramphistomum cervi (or species, which were later considered to be synonymous with P. cervi), but more recently molecular studies demonstrated Calicophoron daubneyi to be the predominating species. For the present investigation, adult rumen flukes isolated from 23 cattle originating from ten farms in Germany (Saxony [1], Baden-Württemberg [4], Bavaria [5]) and one farm in Austria (Tyrol) were analyzed to establish partial sequences of the mitochondrial cytochrome c oxidase subunit I $(C O I)$ and the complete sequence of the nuclear internal transcribed spacer 2 (ITS2). Flukes of five animals (dairy cows from three farms in Bavaria) were determined as P. leydeni, and flukes of 18 animals (dairy cows or cattle from cow-calf operations from eight farms in Saxony [1], BadenWürttemberg [4], Bavaria [2], and Tyrol [1]) were identified as $C$. daubneyi. Based on the molecular analysis of adult rumen flukes collected from cattle, the results of this investigation confirm the common occurrence of $C$. daubneyi in Germany and reveal the first definitive findings of $P$. leydeni in Germany and $C$. daubneyi in Austria.
\end{abstract}

Keywords Paramphistomosis $\cdot$ Calicophoron $\cdot$ Paramphistomum $\cdot$ DNA barcoding $\cdot$ Rumen fluke

\section{Introduction}

Although known for several centuries to parasitize the reticulo-rumen of ruminants, the digenetic trematodes of the family Paramphistomidae have not received much attention for their parasitism in the northern hemisphere until the recent past. Despite having been reported frequently in Europe, rumen fluke infections were

Section Editor: Georg von Samson-Himmelstjerna

Barbara Hinney

Barbara.hinney@vetmeduni.ac.at

1 Institute of Parasitology, Department of Pathobiology, University of Veterinary Medicine Vienna, 1210 Vienna, Austria

2 Institute of Pathology, Department of Pathobiology, University of Veterinary Medicine Vienna, 1210 Vienna, Austria

3 Boehringer Ingelheim Vetmedica $\mathrm{GmbH}$, Kathrinenhof Research Center, Walchenseestr. 8-12, 83101 Rohrdorf, Germany considered apparently as quite uncommon and regarded as of little or no clinical significance (Forbes 2021). The increasing number of reports from continental Europe, the British Isles, and Ireland over the last two decades indicates a growing prevalence of paramphistome infections in domestic ruminants. In this context, outbreaks of disease (acute intestinal paramphistomosis) in both cattle and sheep have been reported from France, the UK, and Ireland (Huson et al. 2017; Wenzel et al. 2019; Forbes 2021).

While the diagnosis of rumen fluke infection is based on gross inspection of the forestomachs for adult flukes, the detection of rumen fluke eggs in feces, or on the recovery of immature flukes in feces or at necropsy, the identification of flukes to species level is challenging (Forbes 2021). The morphological differences, which require fine-structural examination (light and electron microscopy), are quite subtle and prone to be affected by the conditions when flukes were collected. Thus, species identity and taxonomy of the paramphistomes encountered in the infection of ruminants, intermediate 


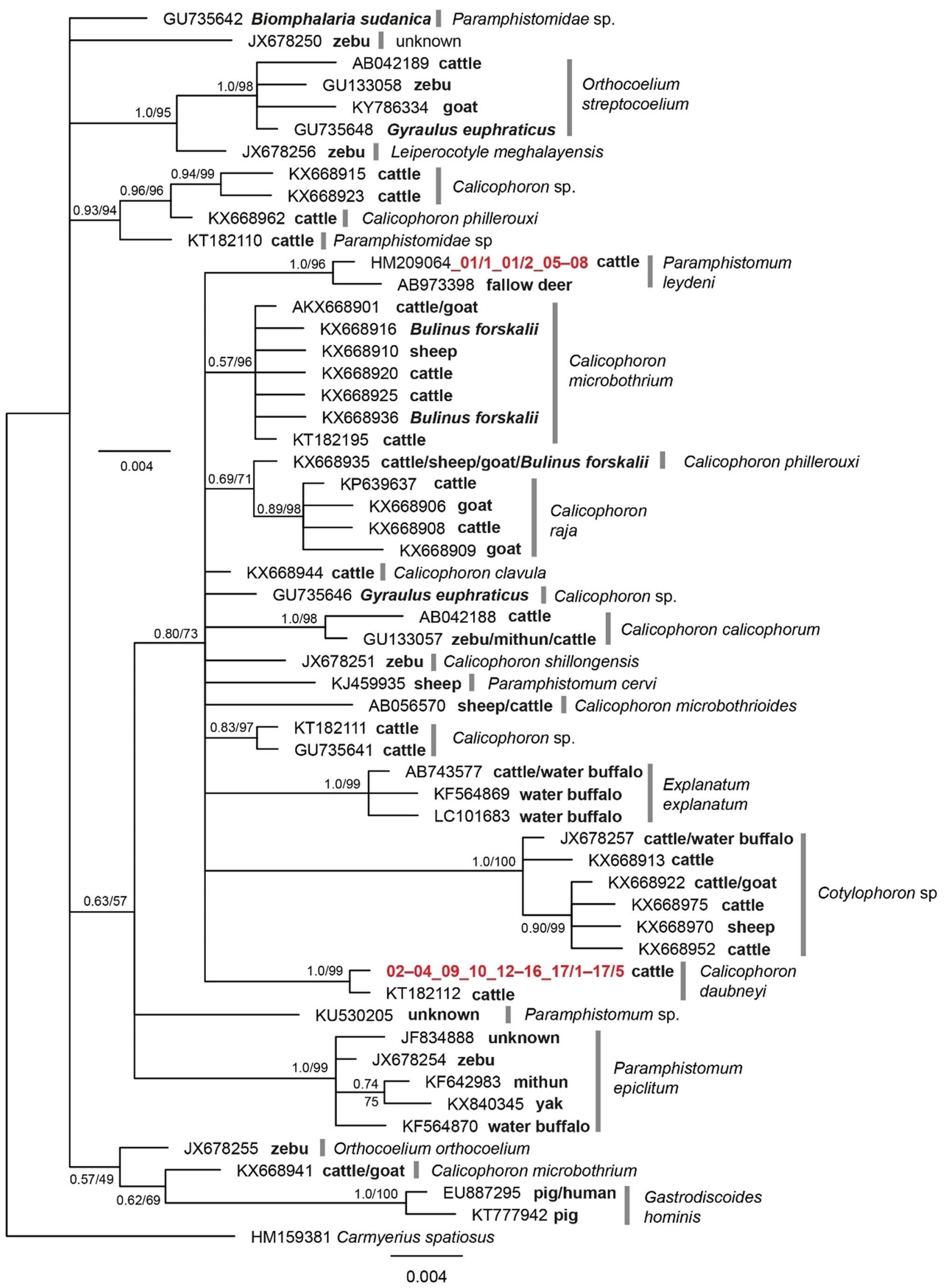


४Fig. 1 Bayesian haplotype tree of ITS2 sequences of Paramphistomidae. Sequences obtained within this study are marked in red and belong to the species $C$. daubneyi and P. leydeni, revealing one haplotype for both species. Nodes are marked with BI posterior probabilities and ML bootstrap values

host specificity and life cycle, have been a matter of intense debate in the 1970s and early 1980s and resulted in several instances in confusion, misidentification, and generation of synonyms (Odening and Gräfner 1979; Sey 1980, 1982; Odening 1983). However, work over the past 15 years has shown that these problems can be addressed using molecular identification methods (Mitchell et al. 2021).

As reviewed by Wenzel et al. (2019), the rate of bovine rumen fluke infection apparently increased in the recent past in Germany, while diagnoses of paramphistomosis in Austria are rare (Hinney, unpublished). Detailed histomorphological examination of rumen flukes in Germany in the 1970s including intermediate host experimental infection studies indicated the occurrence of Paramphistomum cervi, $P$. ichikawei, and Calicophoron daubneyi in cattle (Kraneburg 1977; Odening et al. 1978). In addition, Eduardo (1982) described the presence of $P$. leydeni in cattle from Germany. The latter species was considered synonymous with $P$. cervi by Odening et al. (1978) and Odening (1983). Reviews of parasites of wild ruminants in Austria only list P. cervi as parasite of red deer, roe deer, and mouflon (Kutzer and Hinaidy 1969; Prosl 1973) and, based on fluke histology, records of $P$. cervi and $P$. leydeni from red deer (Eduardo 1982).

Given the limited knowledge on the paramphistome species parasitizing ruminants in both Germany and Austria, flukes collected in the year 2020 when surveying cattle for endoparasites were analyzed using molecular methods to add information on the species identity of rumen flukes from cattle in the two countries.

\section{Material and methods}

For the present molecular study, 35 rumen flukes isolated from 23 cattle were used. The cattle (15 dairy cows, and seven young cattle plus one cow from cow-calf operations) originated from eleven pasture-based farms in Germany (ten farms: Saxony/East Saxony, one farm/five dairy cows; Baden-Württemberg/Black Forest, four cow-calf operation farms/one to three animals per farm; Bavaria/Upper Bavaria, one to three dairy cows from four farms and one animal from one cow-calf operation farm) and Austria (Tyrol, county Kitzbühel/two dairy cows from one farm), and total fluke counts were established by examination of the forestomachs.
Before the analyses, flukes were stored in physiological saline solution or $70 \%$ ethanol. DNA was extracted from the flukes with a High Pure PCR Template Preparation Kit (Roche Diagnostics GmbH, Germany) according to the manufacturer's instructions. Two gene regions were amplified by PCR, a partial sequence of the COI (barcode region), as well as the complete ITS2 sequence.

The ITS2 and the flanking $5.8 \mathrm{~s}$ and $28 \mathrm{~s}$ regions of rDNA were amplified using amphistosome-specific primers (Amph_fwd 5'- TGT GTC GAT GAA GAG CGC AG -3' and Amph_rev 5'- TGG TTA GTT TCT TTT CCT CCG C -'3), resulting in a 500 bp fragment, which is used as genetic markers for rumen fluke species (Itagaki et al. 2003). The reaction was carried out in a volume of $50 \mu \mathrm{l}$, containing $2 \mu$ of DNA template and a final concentration of $1 \times$ GoTaq ${ }^{\circledR}$ green Mastermix (Promega, USA), $0.2 \mathrm{mM}$ dNTPs, $2 \mathrm{mM} \mathrm{MgCl}_{2}, 0.4 \mu \mathrm{M}$ per primer, and $1.25 \mathrm{U}$ of GoTaq ${ }^{\circledR}$ G2 DNA polymerase (Promega, USA). Thermocycling conditions were as follows: initial denaturation at $94{ }^{\circ} \mathrm{C}$ for $2 \mathrm{~min}$ followed by 35 cycles of $94{ }^{\circ} \mathrm{C}$ for $1 \mathrm{~min}$, $55^{\circ} \mathrm{C}$ for $90 \mathrm{~s}$, and $72{ }^{\circ} \mathrm{C}$ for $1 \mathrm{~min}$. A final elongation at $72{ }^{\circ} \mathrm{C}$ for $10 \mathrm{~min}$ ended the program.

A 641 bp section of the mitochondrial COI section was amplified with Neodermata-specific primers (COI_ Neod_FW_5'- TTT ACT TTG GAT CAT AAG CG -3' and COI_Neod_Rv 5'-CCA AAA AAC CAA AAC ATA TGT TGA A -3' (Duscher et al. 2015)). The reaction was set up in a total volume of $50 \mu \mathrm{l}$ containing $2 \mu \mathrm{l}$ of DNA template and a final concentration of $1 \times$ GoTaq ${ }^{\circledR}$ green Mastermix (Promega, USA), $0.2 \mathrm{mM}$ dNTPs, $0.8 \mu \mathrm{M}$ per primer, and $1.25 \mathrm{U}$ of GoTaq ${ }^{\circledR} \mathrm{G} 2$ DNA polymerase (Promega, USA). Thermocycling conditions were as follows: initial denaturation at $95{ }^{\circ} \mathrm{C}$ for $2 \mathrm{~min}$ followed by 35 cycles of $95^{\circ} \mathrm{C}$ for $1 \mathrm{~min}, 48^{\circ} \mathrm{C}$ for $1 \mathrm{~min}$, and $72{ }^{\circ} \mathrm{C}$ for $1 \mathrm{~min}$. A final elongation at $72{ }^{\circ} \mathrm{C}$ for $5 \mathrm{~min}$ ended the program.

All amplicons were checked on 1\% agarose gel stained with Midori Green Advance DNA stain (Nippon Genetics Europe, Germany), and purification and bi-directional sequencing were performed at Microsynth AG, Switzerland.

The sequences were analyzed using Bioedit v.7.0.5.3 (Hall 1999). BLAST searches were performed on NCBI GenBank (http://www.ncbi.nlm.nih.gov/BLAST) to gather all COI and ITS2 sequences of the family Paramphistomidae. The sequences were combined with the new data and the sequences were collapsed before the phylogenetic analysis. Model tests were performed for both data sets using the IQ-tree webserver (http:// iqtree.cibiv.univie.ac.at/ (Trifinopoulos et al. 2016)). Maximum likelihood (ML) trees were calculated using IQ-tree (Minh et al. 2020) with the substitution models $\mathrm{K} 2 \mathrm{P}+\mathrm{I}+\mathrm{G} 4$ for ITS2 and $\mathrm{GTR}+\mathrm{F}+\mathrm{G} 4$ for $\mathrm{COI}$ 
sequences. Bayesian Inference (BI) trees were calculated with MrBayes v.3.1.2 (Huelsenbeck and Ronquist 2001), applying the substitution model GTR $+\mathrm{G}+\mathrm{I}$. The Bayesian analyses were run for $5^{10}$ generations (two runs each with four chains, one of which was heated), sampling every 100 th tree. The first $25 \%$ of trees were discarded as burn-in, and a 50\% majority rule consensus tree was calculated from the remaining 37,500 trees. The nodes in the trees are provided with both BI posterior probabilities and ML bootstrap values.

\section{Results and discussion}

The fluke burden of the 15 dairy cows ranged from one to 536 (median 14); the eight animals from the cow-calf operations harbored 56 to 1231 rumen flukes (median 278). Neither the owners of the animals nor the responsible veterinarians reported clinical signs in the animals that could be related to the infection. The higher burden in the animals from the cow-calf operations compared to the dairy cows may indicate that production systems relying extensively on grazing are likely to favor larger paramphistome burdens. Similar findings with respect to the specific importance of rumen fluke infections for animals from cow-calf operations were recently reported from the Netherlands and Germany based on coproscopical surveys (Ploeger et al. 2017; Forstmaier et al. 2021). The rumen fluke counts fit within the wide range of counts reported from other countries in Europe, i.e., Belgium, France, the Netherlands, and Spain (Szmidt-Adjidé et al. 2000; González-Warleta et al. 2013; Ferreras et al. 2014; Malrait et al. 2015; Ploeger et al. 2017).

By sequencing of a section of the mitochondrial COI, the common DNA barcode sequence, and the complete nuclear ITS 2 sequence of the 35 flukes, six specimens were identified as $P$. leydeni and 29 specimens as $C$. daubneyi. The $P$. leydeni flukes originated from five dairy cows from three farms in Bavaria harboring between one and four flukes. The $C$. daubneyi flukes were diagnosed in ten dairy cows from three farms (Bavaria, Saxony, Tyrol) and the eight animals from cow-calf operations with fluke counts ranging between two and 536 and 56 and 1231 , respectively.

The flukes featured identical ITS2 sequences within the species and several similar $C O I$ lineages. The $C O I$ sequences represent the first DNA-barcodes generated for P. leydeni and C. daubneyi. Bayesian trees of ITS2 and $C O I$ sequences were calculated (Figs. 1 and 2), and the sequences were deposited in GenBank ${ }^{\circledR}$ (Accession numbers COI: MZ519977-MZ520011; accession numbers ITS2: MZ532797-MZ532831). The ITS2 region was used to determine the species affiliation, which proved to be a convenient marker within this group, since it shows inter-specific variation between species of the genus Calicophoron but no or little intra-specific variation (Rinaldi et al. 2005). The COI sequences are the first ones reported for the two species. Hence, the obtained sequences contribute to the molecular identification of paramphistosomes and provide an important basis for future studies.

This molecular investigation reveals the first record of $C$. daubneyi in Austria and it adds evidence for a common occurrence of this species in Germany where C. daubneyi was identified initially in the late 1970 s in eastern Germany based on histomorphology of adult flukes (Odening et al. 1978) and more recently several times using molecular identification of fluke eggs (May et al. 2019; Wenzel et al. 2019; Forstmaier et al. 2021). The findings of this investigation support that $C$. daubneyi is currently apparently the most widespread species of rumen flukes of domestic ruminants in Europe (Wenzel et al. 2019; Forbes 2021). While a just published paper reported the first molecular identification of $P$. leydeni fluke eggs in bovine feces in Germany (Forstmaier et al. 2021), the present investigation features the first molecular proof for the occurrence of $P$. leydeni in Germany based on the examination of adult flukes isolated from cattle. In the past, the histomorphological examination of fluke specimens of bovine origin from Germany led to a controversial interpretation with respect to the identification of $P$. leydeni, which was considered synonymous with $P$. cervi by some authors (Odening et al. 1978; Eduardo 1982; Odening 1983). Using molecular diagnosis, $P$. leydeni has been identified parasitizing cervids in Europe in the recent past, including one case of co-infection with $P$. cervi (O'Toole et al. 2014; Sindičić et al. 2017), but was occasionally identified from fluke eggs excreted by sheep and cattle in Ireland and the Netherlands, respectively (MartinezIbeas et al. 2016; Ploeger et al. 2017).

This investigation was based on an opportunistic sample collection and was of limited extent in regard to the number of flukes examined in total and as to the portion of flukes examined per animal, in particular for the animals which were demonstrated to harbor $C$. daubneyi. Therefore, the occurrence of flukes of species other than $C$. daubneyi in the animals harboring $C$. daubneyi cannot be ruled out. However, to the best knowledge of the authors, no mixed species 
Fig. 2 Bayesian haplotype tree of $C O I$ sequences of Paramphistomidae, sequences obtained within this study are marked in red. Both $C$. daubneyi and P. leydeni featured several similar $C O I$ lineages. Nodes are marked with BI posterior probabilities and ML bootstrap values

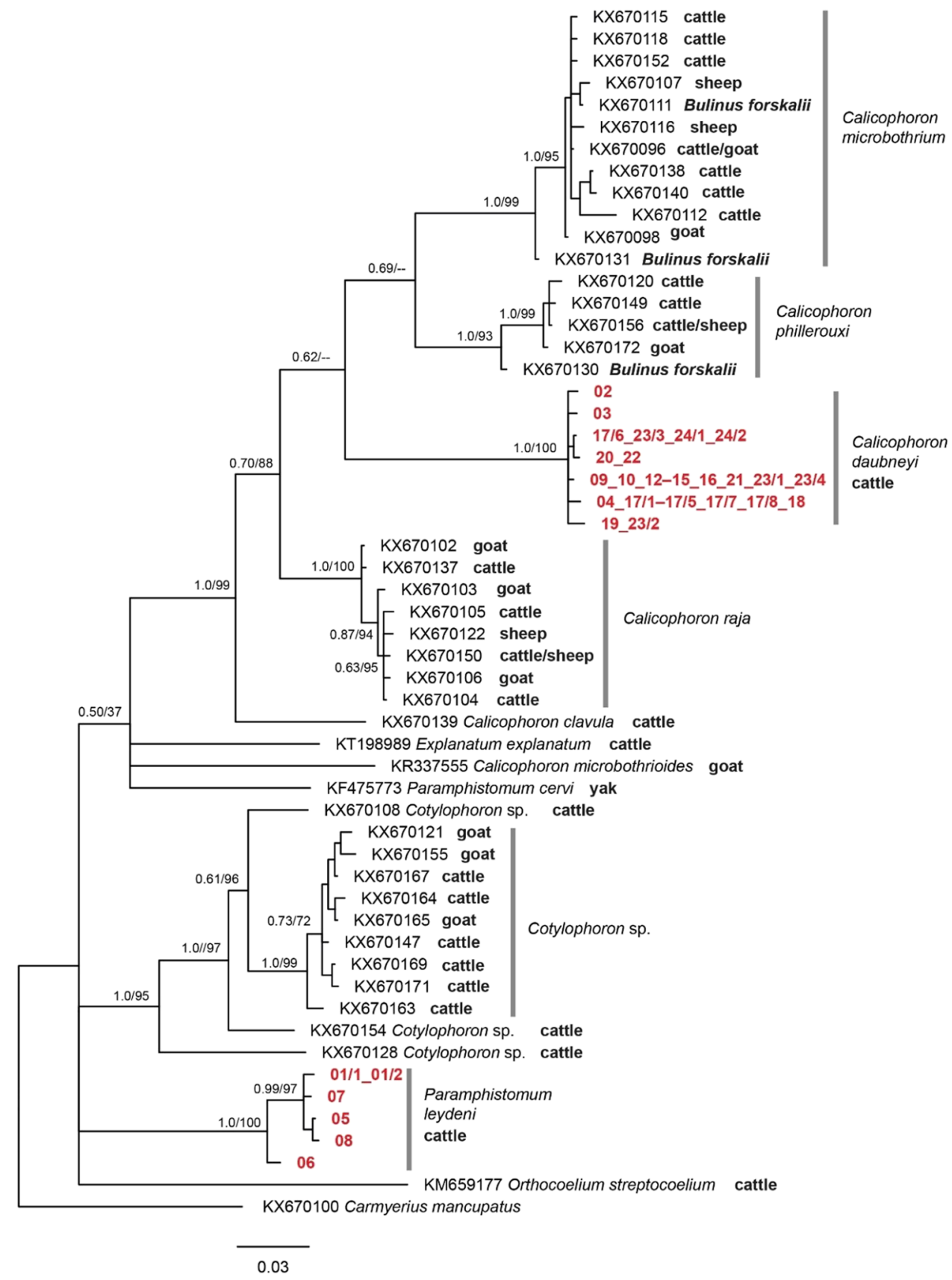

rumen fluke infections have been reported from domestic ruminants in Europe based on molecular diagnosis. Thus, further studies should be conducted to add knowledge on the diversity of species of rumen flukes parasitizing both domestic and wild ruminants in Europe as well as to document their prevalence and the parasite burden.

Acknowledgements The authors thank Mag. Helga Dengg and Dr. Frank Schuster for their assistance in the selection of sources and the collection of the material for the analyses.
Funding Open access funding provided by University of Veterinary

\section{Declarations}

Disclaimer This document is provided for scientific purposes only. Any reference to a brand or trademark herein is for informational purposes only and is not intended for a commercial purpose or to dilute the rights of the respective owner(s) of the brand(s) or trademark(s).

Open Access This article is licensed under a Creative Commons Attribution 4.0 International License, which permits use, sharing, adaptation, distribution and reproduction in any medium or format, as long Medicine Vienna. 
as you give appropriate credit to the original author(s) and the source, provide a link to the Creative Commons licence, and indicate if changes were made. The images or other third party material in this article are included in the article's Creative Commons licence, unless indicated otherwise in a credit line to the material. If material is not included in the article's Creative Commons licence and your intended use is not permitted by statutory regulation or exceeds the permitted use, you will need to obtain permission directly from the copyright holder. To view a copy of this licence, visit http://creativecommons.org/licenses/by/4.0/.

\section{References}

Duscher G, Harl J, Fuehrer H (2015) Evidence of Troglotrema acutum and Skrjabingylus sp. coinfection in a polecat from Lower Austria. Helminthologia 52:163-166. https://doi.org/10.1515/ helmin-2015-0011

Eduardo SL (1982) The taxonomy of the family Paramphistomidae Fischoeder, 1901 with special reference to the morphology of the species occurring in ruminants. II. Revision of the genus Paramphistomum Fischoeder, 1901. Syst Parasitol 4:189-238. https:// doi.org/10.1007/BF00010983

Ferreras MC, González-Lanza C, Pérez V, Fuertes M, Benavides J, Mezo M, González-Warleta M, Giráldez J, Martínez-Ibeas AM, Delgado L, Fernándes M, Manga-Gonzáles MY (2014) Calicophoron daubneyi (Paramphistomidae) in slaughtered cattle in Castilla y León (Spain). Vet Parasitol 199:268-271. https://doi. org/10.1016/j.vetpar.2013.10.019

Forbes AB (2021) Parasites of cattle and sheep. CABI, Wallingford

Forstmaier T, Knubben-Schweizer G, Strube C, Zablotski Y, Wenzel C (2021) Rumen (Calicophoron/Paramphistomum spp.) and liver flukes (Fasciola hepatica) in cattle - prevalence, distribution, and impact of management factors in Germany. Animals 11(9):2727. https://doi.org/10.3390/ani11092727

González-Warleta M, Lladosa S, Castro-Hermida JA, Martínez-Ibeas AM, Conesa D, Muñoz F, López-Quílez A, Manga-González Y, Mezo M (2013) Bovine paramphistomosis in Galicia (Spain): Prevalence, intensity, aetiology and geospatial distribution of the infection. Vet Parasitol 191(3):252-263. https://doi.org/10.1016/j. vetpar.2012.09.006

Hall TA (1999) BioEdit: a user-friendly biological sequence alignment editor and analysis program for Windows 95/98/NT. Nucleic Acids Symp Ser 41:95-98

Huelsenbeck JP, Ronquist F (2001) MrBayes: Bayesian inference of phylogenetic trees. Bioinformatics 17:754-755. https://doi.org/ 10.1093/bioinformatics/17.8.754

Huson KM, Oliver NAM, Robinson MW (2017) Paramphistomosis of ruminants: an emerging parasitic disease in Europe. Trends Parasitol 33:836-844. https://doi.org/10.1016/j.pt.2017.07.002

Itagaki T, Tsumagari N, Tsutsumi K, Chinone S (2003) Discrimination of three amphistome species by PCR-RFLP based on rDNA ITS2 markers. J Vet Med Sci 65:931-933. https://doi.org/10.1292/ jvms.65.931

Kraneburg E (1977) Beiträge zur Biologie und Pathogenität des einheimischen Pansenegels Paramphistomum cervi. 1. Entwicklungsstadien in der Außenwelt und im Zwischenwirt. Berl Münch Tierärztl Wochenschr 90:316-320

Kutzer E, Hinaidy HK (1969) Die Parasiten der wildlebenden Wiederkäuer Österreichs. Zschr Parasitenk 32:354-368. https:// doi.org/10.1007/BF00259648

Malrait K, Verschave S, Skuce P, Van Loo H, Vercruysse J, Charlier J (2015) Novel insights into the pathogenic importance, diagnosis and treatment of the rumen fluke (Calicophoron daubneyi) in cattle. Vet Parasitol 207:134-139. https://doi.org/10.1016/j.vetpar. 2014.10.033
Martinez-Ibeas AM, Munita MP, Lawlor K, Sekiya M, Mulcahy G, Sayers R (2016) Rumen fluke in Irish sheep: prevalence, risk factors and molecular identification of two paramphistome species. BMC Vet Res 12:143. https://doi.org/10.1186/s12917-016-0770-0

May K, Brügemann K, König S, Strube C (2019) Patent infections with Fasciola hepatica and paramphistomes (Calicophoron daub$n e y i)$ in dairy cows and association of fasciolosis with individual milk production and fertility parameters. Vet Parasitol 267:32-41. https://doi.org/10.1016/j.vetpar.2019.01.012

Minh BQ, Schmidt HA, Chernomor O, Schrempf D, Woodhams MD, von Haeseler A, Lanfear R (2020) IQ-TREE 2: New models and efficient methods for phylogenetic inference in the genomic era. Mol Biol Evol 37:1530-1534. https://doi.org/10.1093/molbev/ msaa015

Mitchell G, Zadoks RN, Skuce PJ (2021) A universal approach to molecular identification of rumen fluke species across hosts, continents, and sample types. Front Vet Sci 7:605259. https://doi.org/ 10.3389/fvets.2020.605259

Odening K (1983) Was ist Paramphistomum cervi? Angew Parasitol 24:205-216

Odening K, Gräfner G (1979) Zum systematischen Erforschungsstand der Paramphistomum-Arten (Trematoda) in Europa. Mitt Zool Mus Berl 55:271-290

Odening K, Bockhardt I, Gräfner G (1978) Zur Frage der Pansenegelarten in der DDR (Trematoda: Paramphistomidae) und ihrer Zwischenwirtschnecken. Monatsh Vetmed 33:179-181

O'Toole A, Browne JA, Hogan S, Bassière T, DeWaal T, Mulcahy G, Zintl A (2014) Identity of rumen fluke in deer. Parasitol Res 113:4097-4103. https://doi.org/10.1007/s00436-014-4078-3

Ploeger HW, Ankum L, Moll L, van Doorn DCK, Mitchell G, Skuce PJ, Zadoks RN, Holzhauer M (2017) Presence and species identity of rumen flukes in cattle and sheep in the Netherlands. Vet Parasitol 243:42-46. https://doi.org/10.1016/j.vetpar.2017.06.009

Prosl H (1973) Beiträge zur Parasitenfauna der wildlebenden Wiederkäuer Österreichs. Vet Thesis, Vet Univ Vienna, Austria

Rinaldi L, Perugini AG, Capuano F, Fenizia D, Musella V, Veneziano V, Cringoli G (2005) Characterization of the second internal transcribed spacer of ribosomal DNA of Calicophoron daubneyi from various hosts and locations in southern Italy. Vet Parasitol 131:247-253. https://doi.org/10.1016/j.vetpar.2005.04.035

Sey O (1980) Revision of the amphistomes of European ruminants. Parasitol Hung 13:13-25

Sey O (1982) The morphology, life-cycle and geographical distribution of Paramphistomum cervi (Zeder, 1790) (Trematoda: Paramphistomata). Misc Zool Hung 1:11-24

Sindičić M, Martinković F, Strišković T, Špehar M, Štimac I, Bujanić M, Konjević D (2017) Molecular identification of the rumen flukes Paramphistomum leydeni and Paramphistomum cervi in a concurrent infection of the red deer Cervus elaphus. J Helminthol 91:637-641. https://doi.org/10.1017/S0022149X16000699

Szmidt-Adjidé V, Abrous M, Adjidé CC, Dreyfuss G, Lecompte A, Cabaret J, Rondelaud D (2000) Prevalence of Paramphistomum daubneyi infection in cattle in central France. Vet Parasitol 87:133-138. https://doi.org/10.1016/S0304-4017(99)00168-5

Trifinopoulos J, Nguyen LT, von Haeseler A, Minh BQ (2016) W-IQTREE: a fast online phylogenetic tool for maximum likelihood analysis. Nucleic Acids Res 44(W1):W232-W235

Wenzel C, Küchler A, Strube C, Knubben-Schweizer G (2019) Paramphistomidose - eine Übersicht zu Epidemiologie und klinischer Symptomatik. Tierärztl Prax Ausg G Großtiere Nutztiere 47:184 191. https://doi.org/10.1055/a-0880-6381

Publisher's note Springer Nature remains neutral with regard to jurisdictional claims in published maps and institutional affiliations. 